\title{
Sid \\ First report of Acremonium kiliense causing fruit rot of pears in India
}

\author{
K. Khosla ${ }^{1}$ and A.K. Gupta ${ }^{2}$ \\ ${ }^{1}$ Horticulture Research Station, Dr. YS Parmar University of Horticulture \& Forestry, Seobagh 175138 , Distt Kullu, \\ Himachal Pradesh, India; ${ }^{2}$ Department of Plant Pathology, Dr. YS Parmar University of Horticulture \& Forestry, Nauni 173 \\ 230, Solan, Himachal Pradesh, India \\ *E-mail: kishore.khosla@gmail.com
}

Received: 27 Jan 2016. Published: 04 Apr 2016. Keywords: Pyrus communis, discolouration

Pear (Pyrus communis) is an important pome fruit in India (Food and Agriculture Organization, 1998). For the past three years, during the month of July, a severe outbreak of rotting in immature pear fruits (cv. Bartlett) was observed in five orchards at two locations in the Kullu valley of Himachal Pradesh (Darka and Katrain), India. The rotting symptoms were observed on $70 \%$ of the fruits in each surveyed orchard. Symptoms initially appeared as water-soaked lesions, turning light to dark brown, anywhere on the fruit but primarily from the calyx end (Fig. 1). Initially, the affected fruits were firm but later turned soft. Under the high humidity in JulyAugust, infected fruits became covered with patchy white, arachnoid mycelial growth within 11 to 15 days (Fig. 2). When symptom-bearing fruits were cut open, watery discolouration of interior tissues without browning was observed (Fig. 3).

The pathogen was isolated on potato dextrose agar (PDA) by sampling tissue from the periphery of lesions collected from symptomatic fruit at each location. The samples were sterilised first in $0.01 \%$ mercuric chloride solution for 30 seconds and washed with sterile distilled water three times before transferring to PDA. After incubation at $25^{\circ} \mathrm{C}$ for 12 days, hyphal tips were transferred to fresh PDA and the resulting pure colonies were used for microscopic examination. White colonies that later became dull were arachnoid in appearance. Hyphae were prostrate, hyaline, variously branched, 2.8-7.4 $\mu \mathrm{m}$ in width, obscurely septated and broadly extended (Fig. 4). Abundant globose globules, 3.7-5.6 $\mu \mathrm{m}$ in diameter, were observed in the hyphae. Conidiophores, awl-shaped, verticillate, 25.9-79.6 $\mu \mathrm{m}$ in length and 2.8-5.6 $\mu \mathrm{m}$ in width, arising as upright branches, produced oval hyaline conidia at their tip 3.7-13.0 $\mu \mathrm{m}$ in diameter. Based on the morphological characteristics, the organism was identified as an Acremonium sp. Pure cultures on PDA slants were sent to the National Center of Fungal Taxonomy, New Delhi for final confirmation where the fungus was identified as A. kiliense (ID number 7935.15).

Healthy pear fruits $(n=10)$ were surface sterilised and wounded with a sterilised needle. A $5 \mathrm{~mm}$ diameter mycelial plug from a 15-day-old culture grown on PDA was placed on the wound site. Wounded fruits $(n=5)$ inoculated with only a PDA plug served as controls. All fruits were kept under inverted, sterilised glass jars maintaining high humidity at $25 \pm 1^{\circ} \mathrm{C}$. After 9-10 days, all inoculated fruits developed symptoms similar to those observed in the field (Fig. 5). The pathogen was consistently re-isolated

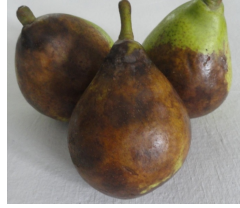

Figure 1

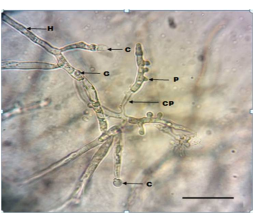

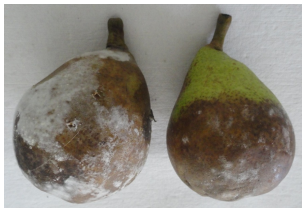

Figure 2

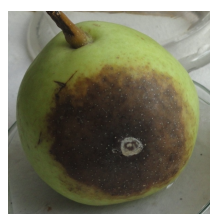

from these fruits to fulfil Koch's postulates. There were no symptoms in the control fruits. Pathogenicity tests were repeated three times.

Acremonium spp. exist primarily as environmental saprobes in the soil and as pathogens of plants and insects (Schell \& Perfect, 1996) often leading to opportunistic infections in both immune-competent as well as immunecompromised human patients (Das et al., 2010). Acremonium strictum has been reported to cause sorghum wilt in India (Bandyopadhyay et al., 1987). Acremonium kiliense has been reported as an endophytic fungus associated with crops such as fennel, lettuce, chicory and celery (D'Amico et al., 2008). To the authors' knowledge, this is the first report of A. kiliense causing fruit rot of pears worldwide. The prevailing high humid conditions during July-August in the orchards may provide an optimal environment for infection.

\section{Acknowledgements}

The authors would like to thank Dr. Shalini Verma and Dr. Anil Handa for their valuable technical assistance.

\section{References}

Bandyopadhyay R, Mughogho LK, Satyanarayana MV, 1987. Systemic infection of sorghum by Acremonium strictum and its transmission through seed. Plant Disease 71, 647-650. http://dx.doi.org/10.1094/PD-71-0647

D’Amico M. Frisullo S, Cirulli M, 2008. Endophytic fungi occurring in fennel, lettuce, chicory, and celery - commercial crops in southern Italy. Mycological Research 112, 100-107.

http://dx.doi.org/10.1016/j.mycres.2007.11.007

Das S, Saha R, Dar SA, Ramachandran VG, 2010. Acremonium species: a review of the etiological agents of emerging hyalohyphomycosis. Mycopathologia 170, 361-375. http://dx.doi.org/10.1007/S11046-010-9334-1

Food and Agriculture Organization, 1998. Production Year Book. Food and Agriculture Organization of the United Nations, Rome, 42, 212.

Schell AW, Perfect JR, 1996. Fatal, disseminated Acremonium strictum infection in a neutropenic host. Journal of Clinical Microbiology 34, 1333-1336.

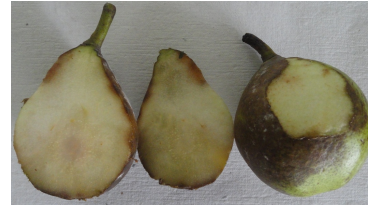

Figure 3

To cite this report: Khosla K, Gupta AK, 2016. First report of Acremonium kiliense causing fruit rot of pears in India. New Disease Reports 33, 14. http://dx.doi.org/10.5197/j.2044-0588.2016.033.014 